\title{
Peningkatan Kualitas Madrasah melalui Sosialisasi Regulasi Akreditasi Sekolah di Madrasah Ibtidaiyah Nurul Jannah NW Ampenan Kota Mataram
}

\author{
${ }^{1}$ Dahlia Hidayati, ${ }^{1}$ Nur Hardiani \\ ${ }^{12}$ Dosen Pendidikan Matematika, UIN Mataram \\ hidayatidahlia@gmail.com,
}

\begin{abstract}
Abstrak. Pengabdian yang dilakukan bertujuan untuk Berangkat dari kerangka berpikir diatas maka pengabdian dengan tujuan peningkatan kualitas madrasah dengan sosialisasi akreditasi menjadi sangat bermakna, mengingat sasaran pengabdian adalah madrasah ibtidaiyah swasta yang berada diwilayah marjinal kota Mataram.

Pelatihan ini akan menggunakan pendekatan pelatihan active learning dimana pembicara hanya merupakan fasilitator dan lebih mengeksplorasi capabilitas audience yang terdiri dari Kepala sekolah, guru dan Tata Usaha sekolah dan melaksanakan rencana tidak lanjut dengan memberikan pemdampingan dan bimbingan teknis sampai dokumen akreditasi dikirim untuk dinilai. Program pelatihan dalam berjalan sesuai rencana, sehingga peserta dapat melihat langsung di LCD dari mempraktekan yang disampaikan oleh narasumber. Para peserta sangat antusias dan senang dalam mengikuti pelatihan. Para peserta mendapatkan tambahan wawasan dan lebih mempersiapkan diri untuk akreditasi madrasah. Rencana tindak lanjut dari kegiatan pengabdian ini memberikan pendampingan selama 2 minggu setelah kegiatan UAS ganjil 2016/2017 sampai pengisian perangkat akreditasi lengkap dan siap dikirim ke badan akreditasi sekolah untuk diberikan penilaian.
\end{abstract}

Kata Kunci: Akreditasi Sekolah, Madrasah Ibtidaiyah

\section{PENDAHULUAN}

Sebagaimana yang diamanatkan dalam Undang undang Dasar Republik bahwa tujuan didirikannya negara adalah untuk mencerdaskan kehidupan bangsa dan setiap warga mempunyai hak yang sama dalam memperoleh pendidikan yang bermutu. ${ }^{22}$ Pembaharuan sistem pendidikan meliputi penghapusan diskriminasi antara pendidikan yang dikelola pemerintah dan pendidikan yang dikelola masyarakat, serta pembedaan antara pendidikan keagamaan dan pendidikan umum. Misi Pendidikan nasional antara lain: mengupayakan perluasan dan pemerataan kesempatan memperoleh pendidikan yang bermutu bagi seluruh rakyat Indonesia. Untuk mewujudkan hal tersebut salah satu upaya yang dilakukan oleh pemerintah Indonesia dalam rangka meningkatkan kualitas pendidikan tersebut dilakukanlah yang disebut dengan akreditasi. Lembaga yang

\footnotetext{
${ }^{22}$ Kitab Undang-Undang sistem Pendidikan Nasional No 20 Tahun 2003
} 
ditujuk untuk melakukan proses tersebut adalah Badan Akreditasi Nasional yang melanjutkan perpanjangan tangan mereka dengan dibentuknya Badan Akrediatasi Propinsi.

Berdasarkan Keputusan Menteri pendidikan Nasional Nomor 087/U/2002, akreditasi sekolah mempunyai tujuan, yaitu: (1) memperolah gambaran kinerja sekolah sebagai alat pembinaan, pengembangan, dan peningkatan mutu; (2) menentukan tingkat kelayakan suatu sekolah dalam penyelenggaraan pelayanan pendidikan. Tujuan akreditasi tersebut berarti bahwa hasil akreditasi itu:

1. Memberikan gambaran tingkat kinerja sekolah yang dijadikan sebagai alat pembinaan, pengembangan dan peningkatan sekolah baik dari segi mutu, efektivitas, efisiensi, produktivitas dan inovasinya.

2. Memberikan jaminan kepada publik bahwa sekolah tersebut telah diakreditasi dan menyediakan layanan pendidikan yang memenuhi standar akreditasi nasional.

3. Memberikan layanan kepada publik bahwa siswa mendapatkan pelayanan yang baik dan sesuai dengan persyaratan standar nasional.

Sehingga diharapkan hasil akreditasi suatu lembaga pendidikan akan memberikan dampak dan beberapa manfaat bagi beberapa kelompok kepentingan, di antaranya adalah sebagai berikut:

1. Sekolah, sebagai acuan dalam upaya meningkatkan mutu pendidikan dan rencana pengembangan sekolah. Bahan masukan untuk pemberdayaan dan pengembangan kinerja warga sekolah. Pendorong motivasi peningkatan kualitas sekolah secara gradual. Selain sebagai sekolah yang berkualitas, sekolah yang terakreditasi ini juga mendapatkan dukungan dari pemerintah, masyarakat maupun sektor swasta dalam hal moral, dana, tenaga dan profesionalisme.

2. Kepala sekolah, sebagai bahan informasi untuk pemetaan indikator keberhasilan kinerja warga sekolah termasuk kinerja kepala sekolah selama 1 periode (4 tahun). Bahan masukan untuk penyusunan anggaran pendapatan dan belanja sekolah. 
3. Guru, dorongan bagi guru untuk selalu meningkatkan diri dari bekerja keras untuk memberi layanan yang terbaik bagi siswanya.

4. Masyarakat (wali murid), sebagai informasi yang akurat untuk menyatakan kualitas pendidikan yang ditawarkan oleh setiap sekolah. Bukti bahwa mereka menerima pendidikan yang berkualitas tinggi, sehingga siswa mempunyai kepercayaan terhadap dirinya bahwa ia mampu masuk dan bersekolah di lembaga pendidikan yang terakreditasi nasional.

5. Dinas pendidikan, sebagai acuan dalam rangka pembinaan dan pengembangan/peningkatan kualitas pendidikan di daerah masing-masing. Bahan informasi penting untuk penyusunan anggaran pendidikan secara umum, dan khususnya anggaran pendidikan yang terkait dengan rencana biaya operasional Badan Akreditasi Sekolah di tingkat Dinas.

6. Pemerintah, sebagai bahan masukan untuk pengembangan sistem akreditasi sekolah di masa mendatang dan alat pengendalian kualitas pelayanan pendidikan bagi masyarakat yang bersifat nasional. Sumber informasi tentang tingkat kualitas layanan pendidikan yang dapat dipergunakan sebagai acuan untuk pembinaan, pengembangan, dan peningkatan kinerja pendidikan secara makro. Bahan informasi penting untuk penyusunan anggaran pendidikan secara umum di tingkat nasional, dan khususnya program dan penganggaran pendidikan yang terkait dengan peningkatan mutu pendidikan nasional.

Sebagaimana dijelaskan pada kerangka pikir di atas akan pentingnya akreditasi sekolah untuk memenuhi standar atau kualifikasi nasional, maka sebagai bentuk perwujudan pengabdian yang tepat dan sesuai dengan observasi awal, sasaran dampingan adalah madrasah yang baru dua belas tahun berdiri dan belum mendapatkan akreditasi secara maksimal. Madrasah Ibtidaiyah ini berada diwilayah marjinal (pinggiran) tepatnya dipesisir pantai Ampenan. Sekolah ini adalah madrasah swasta yang berada di bawah naungan yayasan NW Nurul Jannah. Menurut Data dari BAP propinsi NTB propinsi Nusa Tenggara Barat memiliki sekitar 614 Madrasah Ibtidaiyah, dan baru sekitar 16 sekolah yang 
berpredikat atau terakreditasi sangat baik. Hal tersebut menunjukkan masih banyak pekerjaan rumah yang harus dilakukan oleh banyak pihak untuk mendongkrak mutu dan kualitas sekolah atau pendidikan di NTB, melalui pengabdian ini diharapkan dapat memberikan kontribusi dalam menjawab persoalan sekolah ataupun pendidikan di NTB.

\section{PEMBAHASAN}

\section{Persiapan Kegiatan}

Berdasarkan alokasi waktu yang sudah dibuat oleh tim dosen, sebelum melaksanakan kegiatan pelatihan tim dosen madrasah binaan beberapa kali ke lokasi untuk melakukan observasi awal. Observasi awal bertujuan untuk mendapatkan informasi mengenai sumber daya manusia dan non manusia yang dimiliki oleh MI NW Nurul Jannah Ampenan, berdasarkan observasi awal diperoleh informasi bahwa madrasah ini akan memperpanjang akreditasi tahun 2017. Selanjutnya melakukan wawancara dengan ibu kepala madrasah untuk menanyakan kondisi yang sebenarnya tentang kebutuhan apa saja yang harus dipersiapkan untuk menyusun berkas akreditasi. ${ }^{23}$

Berdasarkan data yang diperoleh dari ibu kepala madrasah, jumlah guru dan non guru yang mengikuti pelatihan kurang lebih sebanyak 12 orang (Data terlampir). Kemudian tim dosen berkoordinasi dengan beberapa nara sumber untuk menentukan hari yang tepat tentang kapan pelaksanaan pelatihan dilakukan. Setelah itu, langkah berikutnya adalah menghubungi yayasan untuk dapat memfasilitasi kegiatan pelatihan ini. Didapatkan pembicara Drs. Arifin, M.Pd, sebagai salah satu tim akreditasi sekolah di LPMP. Selanjutnya tim dosen membuat TOR dan jadwal kegiatan sebagaimana terlampir.

Pihak madrasah sangat senang sekali dengan adanya pelatihan ini dan berharap pelaksanaan kegiatan ini berjalan lancar. Sehingga kegiatan ini bisa menambah wawasan dan data untuk penyusunan dokumen akreditasi. Berdasarkan kesepakatan, diputuskan bahwa kegiatan dilaksanakan pada hari Jumat-Sabtu, 25-26 November 2016 . Langkah akhir dari tahap persiapan ini

\footnotetext{
${ }^{23}$ Observasi \& wawancara dengan kepala madrasah Ibu Nurjannah, Agustus 2016
} 
adalah menyiapkan segala keperluan pelatihan, seperti mengadakan spanduk, Alat Tulis (ATK), Kit pelatihan, snack box (kue kotak), nasi kotak, sertifikat, dan fasilitator.

\section{Objektif Kegiatan}

Akreditasi sekolah/madrasah adalah suatu kegiatan penilaian kelayakan suatu Sekolah/Madrasah berdasarkan kriteria yang telah ditetapkan dan dilakukan oleh BAN-S/M. Dalam pelaksanaan akreditasi sekolah/madrasah tersebut, dibutuhkan kepala sekolah dan guru yang memiliki sikap dan kepribadian yang terpuji, pemahaman dan penguasaan perangkat akreditasi sekolah/madrasah yang memadai, serta memiliki keterampilan menggunakan software aplikasi penskoran dan pemeringkatan hasil akreditasi.

1. Agar dapat terbentuk karakter sebagaimana tersebut di atas, diperlukan kepala sekolah/guru yang memiliki sikap dan kepribadian yang terpuji, pemahaman dan penguasaan perangkat akreditasi sekolah/madrasah.

2. Untuk menjaga kesinambungan kinerja dan peningkatan kompetensi yang dimiliki, perlu dilakukan pelatihan bagi kepala sekolah dan guru yang masa berlaku sertifikatnya telah habis. Pelatihan dapat dilaksanakan oleh BAN-S/M maupun BAP-S/M sesuai Pedoman Akreditasi Sekolah/Madrasah. Tahun 2015 pelatihan dilaksanakan di BAP-S/M. Agar pelatihan akreditasi memiliki kualitas yang sama di seluruh BAP-S/M, maka dibuatlah panduan pelatihan.

a. Outcome

Setelah mengikuti pelatihan, peserta memiliki:

1) sikap dan kepribadian dalam melaksanakan akreditasi sekolah/ madrasah;

2) memahami kebijakan, mekanisme, dan perangkat akreditasi sekolah/madrasah secara komprehensif;

3) keterampilan dalam melaksanakan akreditasi sekolah/madrasah; serta

4) keterampilan mengolah data dan menyusun laporan hasil akreditasi.

b. Materi

1) Peran Akreditasi dalam Penjaminan Mutu Pendidikan

2) Pedoman Akreditasi 
3) Mekanisme Akreditasi

4) Perangkat Akreditasi

5) Keterampilan Berkomunikasi dengan asesor

6) Penyusunan Laporan

a) Pelaksanaan Praktik Penyusunan Akereditasi

b) Menyusun Laporan Individu

c) Menyusun Laporan Kelompok

d) Presentasi Kelompok

\section{Mekanisme Pelatihan}

Beberapa kegiatan dilaksanakan bersama seluruh peserta (pleno), sebagian dalam bentuk kelas, dan sebagian lagi berbentuk kegiatan individu. Selain menerima penjelasan dan contoh dari narasumber, peserta juga akan melakukan pendalaman perangkat akreditasi terutama terkait dengan perubahan terbaru. Di samping itu, peserta juga dibekali dengan teknik menyusun dan menyampaikan laporan akreditasi. Dengan demikian, diharapkan seluruh materi pelatihan dapat dikuasai oleh setiap peserta.

Kegiatan pengabdian madrasah (Madrasah Binaan) dihadiri oleh bapak Ketua Yayasan, Kepala Madrasah, semua guru dan non guru. Beliau selaku ketua yayasan sangat senang dengan adanya pelatihan ini dan beliau berharap kegiatan ini terus berkelanjutan dan berkesinambungan. Setelah acara pembukaan, para peserta diberikan wawasan oleh narasumber dari LPMP. Sesi yang kedua, para peserta diberi pelatihan oleh kepala madrasah. Semua para peserta sangat antusias mengikuti acara pelatihan sampai selesai. Pelatihan ini juga dihadiri oleh Pengawas Madrasah.

Acara Pembukaan dimulai dengan pembacaan Tilawah ayat Suci Al-Qur'an oleh Sri Puji siswa kelas 5 MI NW Nurul Jannah sekaligus sebagai Qori juara III pada acara Lomba MTQ tingkat internal Yayasan. Dilanjutkan dengan Lagu Indonesia Raya. Sambutan diberikan oleh Tim Pengabdian IAIN Mataram, dilanjutkan oleh Kepala Madrasah. Kemudian Do'a disampaikan oleh ustaz Abdul Mun'im S.Pd. Acara dilanjutkan dengan break sejenak. Kemudian pada 10.30 Wita pelatiah dimulai dengan materi peran dan Akreditasi fungsi dan manfaatnya bagi 
Madrasah yang disampaikan oleh nara Sumber dari LPMP. Pada sesi tanya jawab peserta menayakan tentang mekanisme pengajuan akreditasi dari sekolah kemudian ke UPA/Dinas Terkait kemudian ke Badan Akreditasi Propinsi. Peserta menayakan pula peran pengawas dalam mengawal proses akreditasi. Sesi pertama berakhir sampai pukul 12.30 . Sesi selanjutnya dimulai kembali pada pukul 14.00 dan berakhir pada 16.00. Materi pada sesi ini adalah Pedoman dan Mekanisme Akreditasi. Pada sesi tanya jawab peserta menanyakan bagaimana mekanisme bagi sekolah yang sudah pernah mendapatkan sertifikat akreditasi dan bagi madrasah yang sama sekali belum pernah melakukan akreditasi. Hak dan previledge yang mungkin didapatkan oleh sekolah yang telah mendapatkan akreditasi, dan kendala yang dihadapi oleh sekolah yang belum mendapatkan akreditasi.

Sesi berikutnya dilaksanakan pada hari Sabtu 26 November 2016. Sesi pertama dimulai pukul 08.00 sampai 10.00 . Pada sesi ini nara sumber mulai mengarahkan peserta untuk mulai menidentifikasi kekuatan dan kelemahan dai 8 standar akreditasi. Peserta diminta untuk meninventarisir butir butir standar, item mana yang telah dimiliki sekolah yang menjadi kelebihan sekolah, dan item mana yang masih lemah dan tidak memiliki bukti fisik yang memadai. Sesi pengutan standar akreditasi merupakan lanjutan dari sesi pertama dimulai dari 10.00 sampai dengan 12.00. Peserta dibagi menjadi delapan kelompok perstandar dan diminta untuk lebih detai mengidentifikasi bukti fisik yang telah dimiliki perbutir standar. Setelah ishoma pada pukul 13.00-15.00 peserta diminta untuk langsung menyusun bukti-bukti fisik yang dimliki sekolah perstandar dan perbutir standar. Dari kegiatan ini kembali peserta dapat mengetahui, data fisik yang dimiliki dan tdak dimiliki oleh sekolah dan merekomendasikan untuk melengkapinya.

\section{KESIMPULAN}

Sebagai akhir dari laporan kegiatan pengabdian madrasah binaan di MI NW Nurul Jannah, ada beberapa kesimpulan yang dapat dikemukakan:

1 Program pelatihan dalam berjalan sesuai rencana, sehingga peserta dapat melihat langsung di LCD dari mempraktekan yang disampaikan oleh narasumber. 
Transformasi, Vol. 13, No. 2, Juli 2017:219-226

2 Para peserta sangat antusias dan senang dalam mengikuti pelatihan. Para peserta mendapatkan tambahan wawasan dan lebih mempersiapkan diri untuk akreditasi madrasah.

3 Rencana tindak lanjut dari kegiatan pengabdian ini memberikan pendampingan selama 2 minggu setelah kegiatan UAS ganjil sampai pengisian perangkat akreditasi lengkap dan siap dikirim ke badan akreditasi sekolah untuk diberikan penilaian.

\section{DAFTAR PUSTAKA}

Goen, 13 Desember 2013 in Education : akreditasi sekolah, fungsi akreditasi, manfaat akreditasi, prinsip akreditasi, prosedur akreditasi, ruang lingkup akreditasi, tujuan akreditasi

http://akhmadsudrajat.wordpress.com/2008/02/03/akreditasi-sekolah/

http://infopendidikankita.blogspot.com/2012/04/akreditasi-sekolah.html/

http://jakarta.bapsm-dki.or.id/berita/read/tujuan-dan-manfaat-akreditasi/

http://blog.umy.ac.id/mariatulqiftiyah/tujuan-dan-manfaat-akreditasi-suatulembaga-pendidikan/

http://jakarta.bapsm-dki.or.id/berita/read/tujuan-dan-manfaat-akreditasi

Purwanto. Akreditasi Sekolah. [Online]. Tersedia di: http://infopendidikankita.blogspot.com/2009/12/akreditasi-sekolah.html, diakses 1 Desember 2011.

Rif'at, Mohammad, Instrumen Baru Akreditasi Sekolah. [Online]. Tersedia di: http://mohammadrifat.blogspot.com/2010/01/instrumen-baru-akreditasisekolah.html, diakses 1 Desember 2011.

Setiardi, Agus, Prinsip-prinsip Akreditasi. [Online]. Diakses 1 Desember 2011.

Sudrajat, Akhmad, Konsep Akreditasi Sekolah. [Online]. Tersedia di: http://akhmadsudrajat.wordpress.com/ Diakses 1 Desember 2011.

........(2007). Peranan Akreditasi Dalam PeningkatanMutu Pendidikan. [Online]. Tersedia di: http://akreditasi-banten.blogspot.com/, Diakses 1 Desember 2011. 